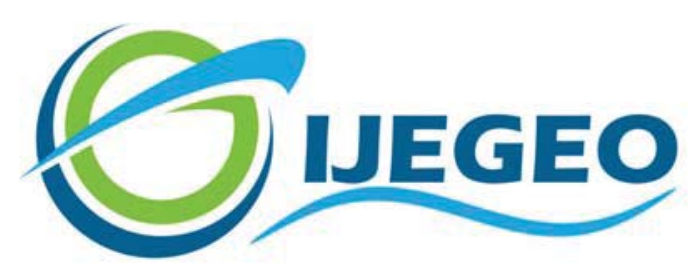

International Journal of Environment and Geoinformatics (IJEGEO) is an international, multidisciplinary, peer reviewed, open access journal.

\title{
An Assessment of Drilling and Blasting Techniques at the Granite Quarry of AFDIN Construction Company Limited, Katsina State, Nigeria
}

\author{
Adamu BALA
}

\section{Chief in Editor}

Prof. Dr. Cem Gazioğlu

\section{Co-Editors}

Prof. Dr. Dursun Zafer Şeker, Prof. Dr. Şinasi Kaya,

Prof. Dr. Ayşegül Tanık and Assist. Prof. Dr. Volkan Demir

Editorial Committee (December 2021)

Assoc. Prof. Dr. Abdullah Aksu (TR), Assit. Prof. Dr. Uğur Algancı (TR), Prof. Dr. Bedri Alpar (TR), Assoc. Prof. Dr. Aslı Aslan (US), Prof. Dr. Levent Bat (TR), Prof. Dr. Paul Bates (UK), İrşad Bayırhan (TR), Prof. Dr. Bülent Bayram (TR), Prof. Dr. Luis M. Botana (ES), Prof. Dr. Nuray Çağlar (TR), Prof. Dr. Sukanta Dash (IN), Dr. Soofia T. Elias (UK), Prof. Dr. A. Evren Erginal (TR), Assoc. Prof. Dr. Cüneyt Erenoğlu (TR), Dr. Dieter Fritsch (DE), Prof. Dr. Çiğdem Göksel (TR), Prof.Dr. Lena Halounova (CZ), Prof. Dr. Manik Kalubarme (IN), Dr. Hakan Kaya (TR), Assist. Prof. Dr. Serkan Kükrer (TR), Assoc. Prof. Dr. Maged Marghany (MY), Prof. Dr. Michael Meadows (ZA), Prof. Dr. Nebiye Musaoğlu (TR), Prof. Dr. Masafumi Nakagawa (JP), Prof. Dr. Hasan Özdemir (TR), Prof. Dr. Chryssy Potsiou (GR), Prof. Dr. Erol Sarı (TR), Prof. Dr. Maria Paradiso (IT), Prof. Dr. Petros Patias (GR), Prof. Dr. Elif Sertel (TR), Prof. Dr. Nüket Sivri (TR), Prof. Dr. Füsun Balık Şanlı (TR), Prof. Dr. Uğur Şanlı (TR), Duygu Ülker (TR), Prof. Dr. Seyfettin Taş (TR), Assoc. Prof. Dr. Ömer Suat Taşkın (TR), Assist. Prof. Dr. Tuba Ünsal (TR), Dr. Manousos Valyrakis (UK), Dr. İnese Varna (LV), Dr. Petra Visser (NL), Prof. Dr. Selma Ünlü (TR), Assoc. Prof. Dr. Oral Yağcı (TR), Prof. Dr. Murat Yakar (TR), Assoc. Prof. Dr. İ. Noyan Yılmaz (AU); Assit. Prof. Dr. Sibel Zeki (TR)

Abstracting and Indexing: TR DIZIN, DOAJ, Index Copernicus, OAJI, Scientific Indexing Services, International Scientific Indexing, Journal Factor, Google Scholar, Ulrich's Periodicals Directory, WorldCat, DRJ, ResearchBib, SOBIAD 


\title{
An Assessment of Drilling and Blasting Techniques at the Granite Quarry of AFDIN Construction Company Limited, Katsina State, Nigeria
}

\author{
Adamu Bala \\ Ahmadu Bello University, Faculty of Environmental Design, Department of Geomatics, Zaria, NIGERIA.
}

E-mail: adamubala09@gmail.com

Received 17.12.2020

Accepted 21.08.2021

How to cite: Bala (2021). An Assessment of Drilling and Blasting Techniques at the Granite Quarry of AFDIN Construction Company Limited, Katsina State, Nigeria, International Journal of Environment and Geoinformatics (IJEGEO), 8(4): 450-459. doi. 10.30897/ijegeo.842565

\begin{abstract}
This research work assessed the Drilling and Blasting Techniques at the Granite Quarry of AFDIN Construction Company Limited, Katsina State, Nigeria. The objectives of the study were to identify drilling and blasting equipment, find out the drilling pattern and parameters, assess the blasting method and its compliance with safety practices in and around the blast site, and review the impact of the blasting operations on the surrounding environment. The concept of drilling and blasting activities and how they affect the immediate environment were examined. The study assessed quarry activities using field visits and interviews. Equipment identified at the quarry were wagon drill, jackhammer, compressors, rock breaker, excavators and tippers, etc. Also, Atlas Copco YT27 jackhammer was the main tool for hole drilling with either square or rectangular drilling pattern being adopted, and drilling dimensions of $4 \mathrm{x} 5 \mathrm{ft}$ or $4 \mathrm{x} 4 \mathrm{ft}$ (spacing and burden) were frequently used at the quarry. Hole depths used were $6 \mathrm{ft}, 8 \mathrm{ft}, 10 \mathrm{ft}$, and $12 \mathrm{ft}$ and drilling bit of 1-inch or 2-inch. The study estimated that $2,088.95 \mathrm{~kg}$ of explosives (10\% high explosive and $90 \%$ low explosive) was used to charge 2000 drilled holes with an average hole depth of 3.65 metres and a diameter of $32 \mathrm{~mm}$ respectively. A total of 7,394 tonnes of granite rock was blasted. Results from immediate blasting at the quarry indicated the presence of dust and fumes within the quarry environment and nearby villages, inhalation of which could lead to serious occupational hazards. Conclusively, explosion sound from blasting and fly-rock fragments were found to have some serious environmental and health effects on both workers and neighbouring communities in terms of noise pollution and vibration effects on structures. Dust suppression of the environment by continuous wetting of the ground and crushing process was recommended to minimise dust generation to protect workers from occupational diseases such as silicosis and Pneumoconiosis. Wearing of personal protective equipment, electric blasting method, corporate social responsibilities to the communities were also recommended.
\end{abstract}

Keywords: Assessment, Drilling and Blasting, Granite Quarry, Powder factor, Quarry Environment, Katsina

\section{Introduction}

Mining is one of the oldest occupations of mankind, next only to hunting, gathering, and domestication of plants and animals. Drilling and blasting play a vital role in mining projects. They are required in most surface mining operations. Mineral exploitation brings income and reduces unemployment thereby creating wealth for a nation and its citizens. However, despite their positive contribution to the economy, they also impact negatively on the physical environment. This is because mining and extraction cannot be done successfully without causing environmental effects (Bala, 2018). Drilling can be described as the boring of a cylindrical hole into a rock mass inclined horizontally, vertically, of suitable diameter for insertion of explosives to fragment a rock (Awwal, 2017). Drilling is also used in surface mining for purposes other than providing blast holes (Kennedy, 2009). It finds application during exploration for obtaining drill hole samples and during development for drainage, slope stability, and foundation-testing purposes. In the mining cycle, drilling performed for the placement of explosives is termed production drilling. Drilling is very essential for many quarry activities, this is because only the weakest rock, if loosely consolidated or weathered, can be broken without explosives, using mechanical excavators or other means (Kennedy, 2009).

Researchers have carried out several works on drilling and blasting techniques in line with best practices in the mining industry.Tejado et al. (2016) reported that workers in the granite industry face a serious health and safety hazard. The procedures for extracting and processing granite can generate a large quantity of granite dust in the workers' environment. The inhalation of this dust poses a hazard due to its high crystalline silica content, which, when deposited in the lungs, gives rise to silicosis (Nandi et al. 2018; Ahmad, 2015; and Yadav et al. 2011). Because of exposure to silica dust, silicosis is a lung disease contracted as an occupational hazard by workers in the mining, sands blasting, quarrying, ceramics, and foundry industries as well as grinders, etc (Singh, 2020). Awwal (2017) reviewed modern blasting techniques at Dangote Cement Company, Obajana, Kogi State, Nigeria. He suggested that the blasting techniques used at the company should be adopted by other mining industries to achieve better blasting results at minimum costs using a good blast design. In designing a blast, it is necessary to consider the parameters such as bench height, blast hole diameter, 
burden between rows, spacing between blast holes, subgrade, stemming, and explosives properties that would deliver optimum fragmentation of rock (Sergey, et al., 2017). Regotunov et al. (2020) reported that changing the bit design for specific rocks; drilling method; drilling mode; boring rig design; controlled parameters of the drilling process and rock properties redetermination among other factors contribute to the growth of drilling performance. They construed that it is possible to predict changes of individual factors depending on changes of other factors, not functionally related directly when planning drilling operations. Aryafar et al. (2020) used Analytic Hierarchy Process (AHP) and other methods to select the most proper drilling and blasting pattern in Sangan Iron Mine, Iran. He reported that, drilling pattern with a spacing of $5 \mathrm{~m}$, burden $4 \mathrm{~m}$, hole depth $10 \mathrm{~m}$, and hole diameter $15 \mathrm{~cm}$ was the most suitable one. The stemming length and powder factor of the suggested pattern were $2.3 \mathrm{~m}$ and $2.6 \mathrm{gr} / \mathrm{cm}^{3}$. Similarly, Sadeghi et al. (2019) applied Artificial Neural Network (ANN) and Decision Tree (DT) techniques to predict toe resulting from blasting. Hawzak limestone mine in Iran was used as a case study area in which 100 blastings were considered and collected. When the two techniques were tested, the ANN technique provided higher performance capacity for the prediction of toe induced by blasting.

Likewise, Kononenko et al. (2019) developed a new method for designing drilling-and-blasting operations parameters during underground mining through the application of emulsion explosives taking into consideration their energy characteristics along with the physical and mechanical properties of rocks. The methodological approach included analytical transformations, improvement, and computer modelling of drilling and blasting operations parameters based on a finite element method. Results from findings revealed a new algorithm for calculating parameters for drawing up the passport of drilling-and-blasting operations during underground mining. Jahed et al. (2015) predicted the blasting environmental impacts in granite quarry in Malaysia. They investigated 166 blasting operations at four granite quarry sites. Values of peak particle velocity, air overpressure, and flyrock were recorded in each blasting operation. Results demonstrated that Adaptive Neuro-Fuzzy Inference System (ANFIS) models yielded higher performance capacity compared to ANN models. Armaghani et al. (2020) predicted the flyrock distance with the use of machine learning techniques. Six mines and 262 data samples of blasting operations were used as case studies in which the most effective parameters of flyrock were measured during blasting operations in the mines. Principal Component Regression (PCR), Support Vector Regression (SVR), and Multivariate Adaptive Regression Splines (MARS) machine learning methods were used in the evaluation and estimation of flyrock. Findings showed that the SVR prediction model can be used to accurately predict flyrock distance, thereby properly determining the blast safety area. Singh, (2020) and Tejado et al. (2016) worked on the risk of occupational hazard. Tejado et al. (2016) reported that workers in the granite factory face no significant additional radiological exposure, whereas Singh (2020) suggested preventive and remedial measures to avoid disease such as silicosis. The explosions at Akure, capital of Ondo State, Nigeria on $28^{\text {th }}$. March, 2020 and in the Lebanon capital, Beirut on $4^{\text {th }}$. August, 2020 claiming hundreds of lives call for observation of best practices in handling explosives for blasting operations considering the underlining importance of their use in the mining industry. This study, therefore, attempts to carry out a comprehensive technical assessment of drilling and blasting operations at the granite quarry of AFDIN Construction Company Limited, Katsina, to determine the extent of best practices compliance.

\section{Location and Description of the Study Area}

The rock type in the study area is porphyritic biotite granite (Jack, 2018). The AFDIN construction company Quarry and Crushing Plant are located at Barawa village, along Katsina-Batsari road (Figure 1). It is a subsidiary of AFDIN Construction Company Limited, Katsina whose company`s headquarters are located at Katsina with branches in Kaduna and Abuja respectively. The quarry site is situated between Latitude $12^{\circ} 55^{\prime} 03^{\prime \prime}$ to $12^{\circ} 55^{\prime} 12^{\prime \prime} \mathrm{N}$ and Longitude $7^{\circ} 30^{\prime} 11^{\prime \prime}$ to $7^{\circ} 30^{\prime} 19^{\prime \prime} \mathrm{E}$, about $16 \mathrm{~km}$ from Katsina metropolis. At the quarry and crushing plant, works are carried out using different machines and tools. In the quarry, granite rocks are drilled, blasted, and hauled to a crushing plant for the production of aggregate gravels in different sizes. The quarry and crushing plant have 26 employees (both technical and non-technical staff) working from Monday to Saturday (except on public holidays); eight (8) hours per working day and Sundays are used for maintenance. Each staff has duties assigned to them, although they could be deployed to the quarry or the crushing plant according to production requirements.

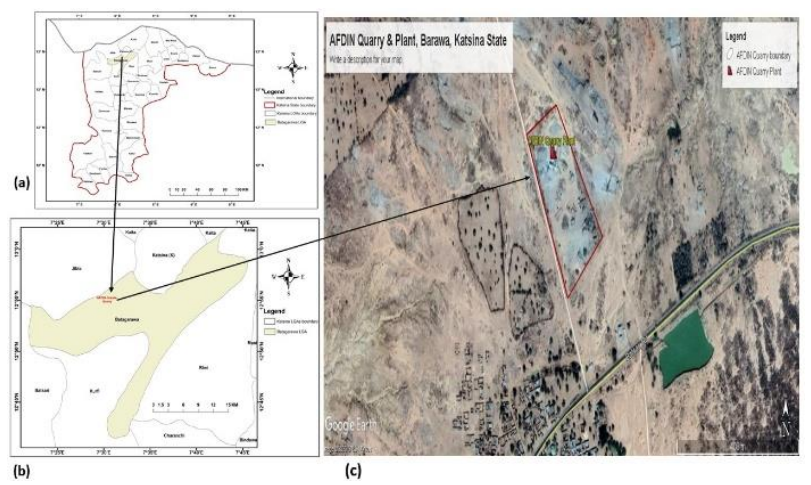

Figure 1: Locational maps: (a) Katsina State (b) Batagarawa LGA (c) AFDIN quarry and plant

The company is engaged in quarrying operations and production of aggregates of mainly four (a half-inch, threequarter, three-eight, and dust) sizes, used by the company in executing its construction project; and in most cases the aggregates are not sold to the third party. The quarry phase and plant are headed by the Quarry/Asphalt/Blending plant manager as shown in Figure 2. 


\section{Materials and Methods}

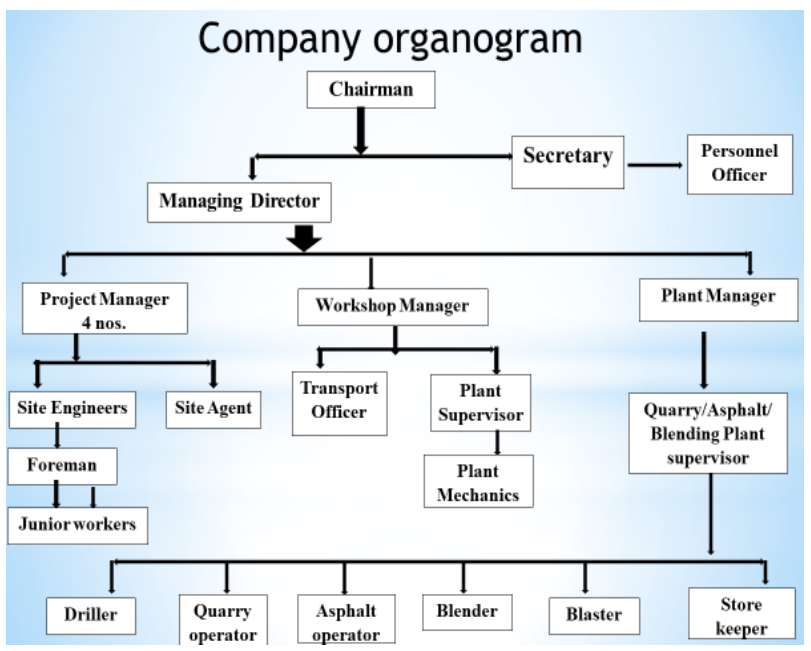

Figure 2: Organogram of AFDIN Construction Company Limited, Katsina

Table 1: Equipment, Devices and Tools on Site

\begin{tabular}{llll}
\hline S/No. & Name & Model/Description & Uses/Purpose \\
\hline 1 & Wagon Drill & Atlas Copco ROC 601 (type & For drilling blast holes \\
& & BVB 72)
\end{tabular}

$\begin{array}{llll}2 & \text { Jackhammer } & \text { Atlas Copco YT27 } & \text { For drilling blast holes } \\ 3 & \text { Compressor } & \text { Atlas Copco SILIT-WERKE D- } & \text { Attached to the Wagon Drill through a Hosepipe } \\ & 8872 \text { Burgau }\end{array}$

\begin{tabular}{|c|c|c|c|}
\hline \multirow[t]{2}{*}{4} & \multirow[t]{2}{*}{ Compressor } & \multirow[t]{2}{*}{ Јopco XA5 186} & \multirow{2}{*}{$\begin{array}{l}\text { i. produces air for flushing drilled holes } \\
\text { ii. Jackhammer is usually connected to this } \\
\text { compressor }\end{array}$} \\
\hline & & & \\
\hline 5 & Rock Breaker & EDT 6500F & $\begin{array}{l}\text { For resizing very big boulders to the sizes the crusher } \\
\text { feeder can accommodate }\end{array}$ \\
\hline 6 & Excavator & CMAX SC $360-8$ & $\begin{array}{l}\text { Rock Breaker is attached to it for mobility and } \\
\text { optimum results }\end{array}$ \\
\hline 7 & Excavator & SY335C & $\begin{array}{l}\text { For loading the blasted rocks on Tippers at the } \\
\text { Quarry }\end{array}$ \\
\hline 8 & Excavator & CAT 345CL & For hauling rock aggregates \\
\hline 9 & Tipper & MAN Diesel 10 tyres, $11 \mathrm{~cm}^{3}$ & $\begin{array}{l}\text { For transporting blasted rocks from Quarry to the } \\
\text { Crushing Plant }\end{array}$ \\
\hline 10 & Tipper & DAF 10 tyres, $11 \mathrm{~cm}^{3}$ & $\begin{array}{l}\text { For transporting blasted rocks from Quarry to the } \\
\text { Crushing Plant }\end{array}$ \\
\hline 11 & Drilling bit & 0.9 inch & Accessory for drilling blast holes \\
\hline 12 & Drilling rod & $5.42 \mathrm{~mm}$ & Accessory for drilling blast holes \\
\hline 13 & Tape & $50 \mathrm{~m}$ & $\begin{array}{l}\text { For measurement of spacing and burden during } \\
\text { drilling }\end{array}$ \\
\hline 14 & Handheld GPS & 76CSX & For field navigation and marking new outcrop \\
\hline
\end{tabular}

The Equipment, Devices, and Tools available at the Quarry and their description are shown in Table 1. Other tools, facilities, devices, and software packages relevant to the research were employed as well. These include: 
ANFO (Ammonium Nitrate Fuel Oil) and Giletin

$>$ Safety fuse, detonating cord and blasting cap/plain detonator (for igniting the blasting)

$>$ Sand/Soil/dry chips for stemming

$>$ Personal Protective Equipment (Ear muffler, Goggle glasses, Safety helmet \& boot, etc)

$>\quad$ Digital camera and Field record book

$>$ Google Earth Pro (for additional navigation and producing study area inset map)

$>$ ArcGIS v10.7 (for producing study area inset map)

\section{Drilling Procedure}

Drilling at AFDIN Quarry has been mainly of a primary kind, though in some rare cases secondary drillings are carried out especially for very big boulders $(0.5-5 \mathrm{~m})$ that the Rock breaker/cutter could not handle.

Atlas Copco YT27 Jackhammer and Atlas Copco ROC 601 Wagon Drill are the two types of equipment used for the drilling of holes depending on the quarry face size, nature of the rock, etc. The company adopts either Square or Rectangular drilling patterns. Tables 2 and 3 show the various drilling pattern adopted by the company.

Table 2: Drilling Pattern using Atlas Copco YT27 Jackhammer

\begin{tabular}{llll}
\hline S/ & Drillin & Drillin & Remarks \\
$\mathbf{N}$ & $\mathbf{g}$ & $\mathbf{g}$ & \\
$\mathbf{0}$ & dimens & Patter & \\
& ions & $\mathbf{n}$ & \\
\hline 1 & $2 \times 2 \mathrm{ft}$ & Square & $\begin{array}{l}\text { Used for smaller boulders } \\
\text { production }\end{array}$
\end{tabular}

\begin{tabular}{|c|c|c|c|}
\hline 2 & $3 \times 2 \mathrm{ft}$ & $\begin{array}{l}\text { Rectan } \\
\text { gular }\end{array}$ & $\begin{array}{l}\text { Used for middle size boulders } \\
\text { production ( } 3 \text { is the spacing and } \\
2 \text { is the burden) }\end{array}$ \\
\hline 3 & $4 \times 5 \mathrm{ft}$ & $\begin{array}{l}\text { Rectan } \\
\text { gular }\end{array}$ & $\begin{array}{l}4 \times 5 \mathrm{ft} \text { or } 4 \times 4 \mathrm{ft} \text { are frequently } \\
\text { used at the AFDIN Quarry }\end{array}$ \\
\hline 4 & $4 \mathrm{x} 4 \mathrm{ft}$ & Square & $\begin{array}{l}4 \times 5 \mathrm{ft} \text { or } 4 \times 4 \mathrm{ft} \text { are frequently } \\
\text { used at the AFDIN Quarry }\end{array}$ \\
\hline
\end{tabular}

Table 3: Drilling Pattern using Atlas Copco ROC 601 Wagon Drill

\begin{tabular}{|c|c|c|c|}
\hline $\begin{array}{l}\mathrm{S} / \\
\mathbf{N} \\
\mathbf{0}\end{array}$ & $\begin{array}{l}\text { Drilling } \\
\text { dimensi } \\
\text { ons }\end{array}$ & $\begin{array}{l}\text { Drilling } \\
\text { Pattern }\end{array}$ & Remarks \\
\hline 1 & $1 \mathrm{x} 1 \mathrm{~m}$ & Square & $\begin{array}{l}\text { This pattern is often used at } \\
\text { the Quarry }\end{array}$ \\
\hline
\end{tabular}

\begin{tabular}{llll}
2 & $2 \times 2 \mathrm{~m}$ & Square & $\begin{array}{l}\text { Sometimes used depending } \\
\text { on the nearness to settlement }\end{array}$ \\
3 & $2 \times 1 \mathrm{~m}$ & $\begin{array}{l}\text { Rectang } \\
\text { ular }\end{array}$ & $\begin{array}{l}\text { This pattern is frequently } \\
\text { used at the Quarry }\end{array}$ \\
\hline
\end{tabular}

Drilling hole parameters used by the company vary depending on the device used for the drills. For the Jackhammer, the following drilling dimensions are used
$>$ Depth: $6 \mathrm{ft}, 8 \mathrm{ft}, 10 \mathrm{ft}$, and $12 \mathrm{ft}$, in some cases hilly outcrops require higher depth

$>$ 1-inch, 2-inch and 3-inch drill bits but 1-inch and 2-inch drill bits are frequently used, 1-inch can also be used conveniently to retrace 2 -inch size holes. At the quarry, tree leaves and some shrubs were used to cover the drilled hole top after drilling, to avoid them being filled with water, sand or materials especially in the rainy season

Even though the openings of the holes were usually covered with leaves to avoid siltation, the holes drilled sometimes get filled up with water or silted with sand, or dry leaves especially whenever it rains after drilling. Therefore, there was a need for the holes to be cleaned up using air pressure. Air compressor was normally used to flush out water and silted materials from the drill holes before charging. A 1-inch hosepipe is used for flushing 2-inch diameter drill holes whereas a 0.5 -inch hosepipe is used for flushing 1-inch diameter drill holes.

\section{Explosives and Charging of Blast Holes}

Blast holes charging refers to the filling up of blast holes subsequently with explosive and earth materials. It is classified into three parts: stemming, column charge, and bottom charge. A charge of explosives should not occupy more than $2 / 3$ of blast hole depth. There were two common explosives used for blasting at the Quarry:

$>$ ANFO (96\% Ammonium Nitrate and 4\% Fuel Oil) and

$>$ Giletin. Because the materials used for the charging get dissolve in wet areas, two methods are used for the charging depending on the dry and rainy season. For Dry Season, ANFO is usually used as an explosive where the detonating cord (blue) is inserted to the bottom of the drilled holes and then ANFO is poured up to $2 / 3$ of the drilled hole depth. For Rainy Season, Giletin is used for the hole charging:

$>2$ pieces for $6 \mathrm{ft}$ hole depth; 3 pieces for $8 \mathrm{ft}$ hole depth; 4 pieces for $10 \mathrm{ft}$ hole depth and 5 pieces for $12 \mathrm{ft}$ hole depth. Sometimes, ANFO is poured on top of Giletin, in which $2 \mathrm{ft}$ quantity of ANFO on top the Giletin for the $6 \mathrm{ft}$ hole depth, $3 \mathrm{ft}$ quantity of ANFO on top the Giletin for $8 \mathrm{ft}$ hole depth, $4 \mathrm{ft}$ quantity of ANFO on top the Giletin for $10 \mathrm{ft}$ hole depth and $5 \mathrm{ft}$ quantity of ANFO on top the Giletin for $12 \mathrm{ft}$ hole depth. The combination of ANFO and Giletin increases rocks breakages efficiency though it also increases the cost of operations.

Stemming consists of filling up an uncharged top part of the blast hole with drilling chips or sandy clay materials etc. to prevent the explosion gas vent out from the hole. As a rule of thumb, stemming length occupies $1 / 3$ of the hole length. During stemming at the quarry, sandy materials were used to fill the remaining $1 / 3$ of the hole depth. The purpose of this was to prevent air or gas from coming out during an explosion which if allowed, will reduce the pressure and strength of the energy at the 
explosion. If the stemming length is too small, it will generate flyrock and air blast problems. Also, if the stemming length is too long this will give poor fragmentation of the rock above column charge

\section{Wiring of Detonating Cord and Blasting}

All the detonating cords were connected from various drilled holes to form a series of networks. The detonating cord was sometimes crisscrossed to the edges of the blast area boundary (Figure 12) to reduce rock fly especially if the quarry is near a crushing plant and /or settlement.

The detonator (small silver fuse, Figure 7c) cap was normally fixed at the edge of the detonating cord wiring angle to face opposite of quarry so that the blast rocks will fall towards the quarry face. For instance, if the quarry plant is in the East, detonator cap should be fixed at North or South of the quarry face but if the quarry is far away from crushing plant, settlements, or machines, detonator cap can be placed at any angle.

The safety fuse was attached to the detonator cap and the detonator linked to the detonating cord. A safety fuse wire was then used to initiate and transfer the fire to the detonator cap for prompt blasting, ones the heat touches and ignites the detonator cap, blasting occurs.

Secondary blasting: where the boulders were bigger than the crusher feeder, a rock breaker might be used to resize the boulders to a required size. Secondary blasting at the study area was being supplemented by a rock breaker/cutter which breaks minimum sizeable boulders that were too small to blast and also too big for the crusher to handle

\section{Weight of Charge of Explosive per Hole (kg)}

Explosive loading factor or specific charge or powder factor $(\mathrm{q}),\left(\mathrm{kg} / \mathrm{m}^{3}\right),(\mathrm{kg} / \mathrm{T})$ is the consumption (planned or actual) of explosive per cubic metre or a metric ton of rock. It is a yardstick determining how much explosive is required to break a particular rock mass. It is also the mathematical relationship between the weight of explosive $(\mathrm{kg})$ and a quantity of rock $\left(\mathrm{m}^{3}\right)$ needed to break down a unit volume of rock mass, $\mathrm{H}$ which may be expressed as $\mathrm{lb} / \mathrm{s}$ ton, $\mathrm{kg} /$ tonne, $\mathrm{lb} / \mathrm{yd}^{3}$, or $\mathrm{kg} / \mathrm{m}^{3}$. It has a direct relationship with the type of explosive, the weight of the explosive, hole spacing and burden, and hole diameter.

A cubic metre per blast hole of specific charge was calculated using:

$$
\mu=\mathrm{B} \times \delta \times \mathrm{H}
$$

\section{Equation 1.}

where $\quad \mu=$ Rock volume $\left(\mathrm{m}^{3}\right)$;

$\delta=$ Spacing dimension $(\mathrm{m})$;

$\mathrm{B}=$ Burden dimension $(\mathrm{m})$ and

$\mathrm{H}=$ Bench height/ hole depths (m)

If a ton of rocks per blast hole is required, then it could be deduced by multiplying rock volume by the density of rock (ton/cubic metre).

Therefore,

the Total tonnage of the rock materials $=$

Rock Volume $(\mu)$ x Density of rock $\left(T / \mathrm{m}^{3}\right)$ x Number of holes (n) Equation 2.

The Granite rock solid density is given as $2.72 \mathrm{~T} / \mathrm{m}^{3}$ Quantity of Explosive required =
Total Tonnage x Powder factor Equation 3. Quantity of High Explosive to Low Explosive (ANFO): H. E. $=10 \%$ and L. E. $=90 \%$

In surface blasting, the normal explosive/powder factor for a hard granite rock is between $0.7-0.8 \mathrm{~kg} / \mathrm{m}^{3}$. At the quarry a value of $0.8 \mathrm{~kg} / \mathrm{m}^{3}=0.2825173338 \mathrm{~kg} / \mathrm{T}$ was used as the powder factor.

\section{Results of Quarry Equipment/Devices and Tools}

Figures (2-3) showed the two types of compressors available at the AFDIN quarry. The Atlas Copco SILITWERKE D-8872 Burgau Compressor model in Figure 1 is usually attached to the Wagon Drill through a tube pipe for the supply of air pressure. Likewise, the Atlas Copco XA5 186 model Compressor in Figure 2 is attached to the Jackhammer shown in Figure $4 \mathrm{a}$ for supplying air pressure for drilling of holes and also for flushing drilled holes. Only Atlas Copco XA5 186 model Compressor was used at the time of the fieldwork.

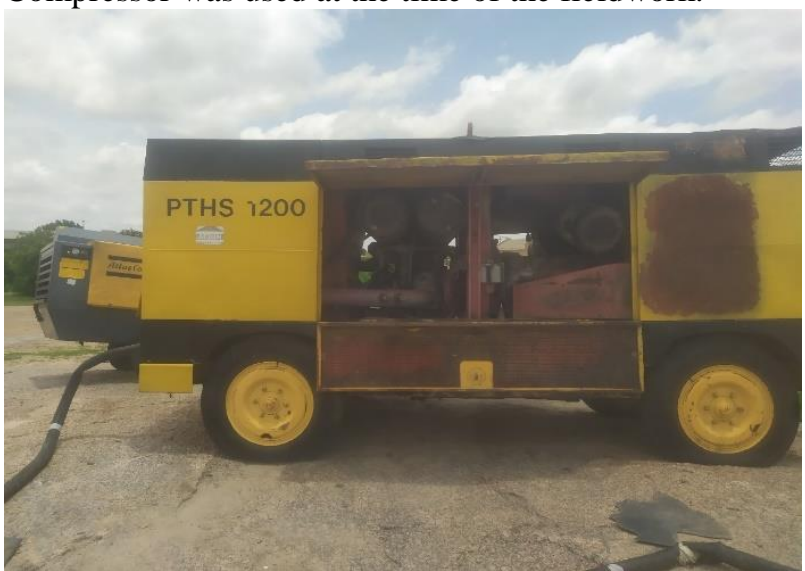

Figure 2: Atlas Copco SILIT-WERKE D-8872 Burgau Compressor

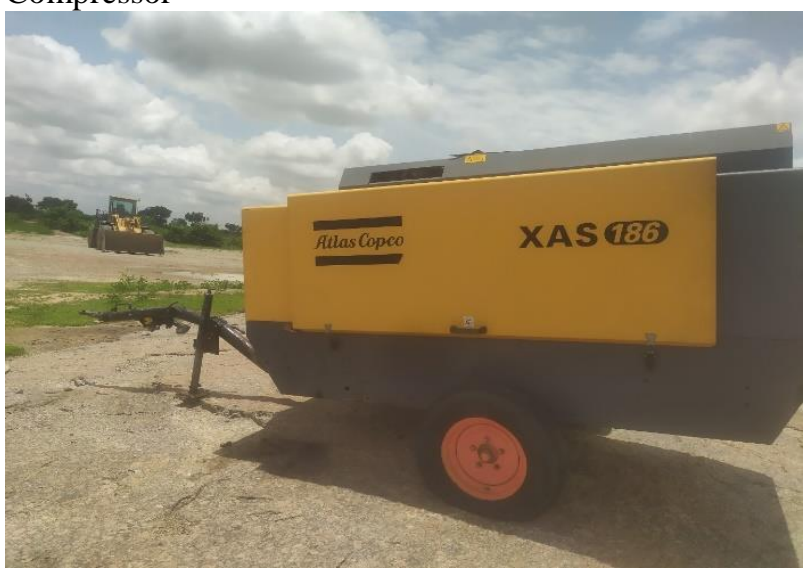

Figure 3: Atlas Copco XA5 186 Compressor

\section{Drilling machines and tools:}

Figure 3 and Figure $4 \mathrm{a}$ shown the two types of drilling machines at the AFDIN Quarry. The Atlas Copco ROC 601 (type BVB 72) Wagon Drill in Figure 3 is attached to the compressor in Figure 1, whereas the Atlas Copco YT27 Jackhammer is attached to the compressor in Figure 2. The Jackhammer powered by compressed air was used for the blast hole drilling throughout this work, and the Wagon drill was not used. Figure $4 \mathrm{~b}$ is a drill bit that was attached with a drill rod onto the Jackhammer. Drill bits are in different sizes and their choice depends on the blast hole diameter required. 


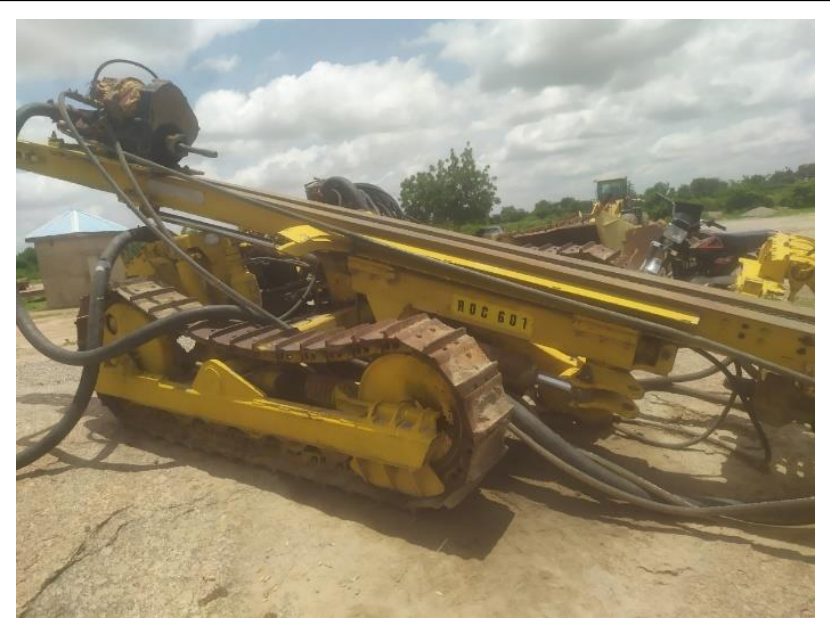

Figure 3: Atlas Copco ROC 601 (type BVB 72) Wagon Drill
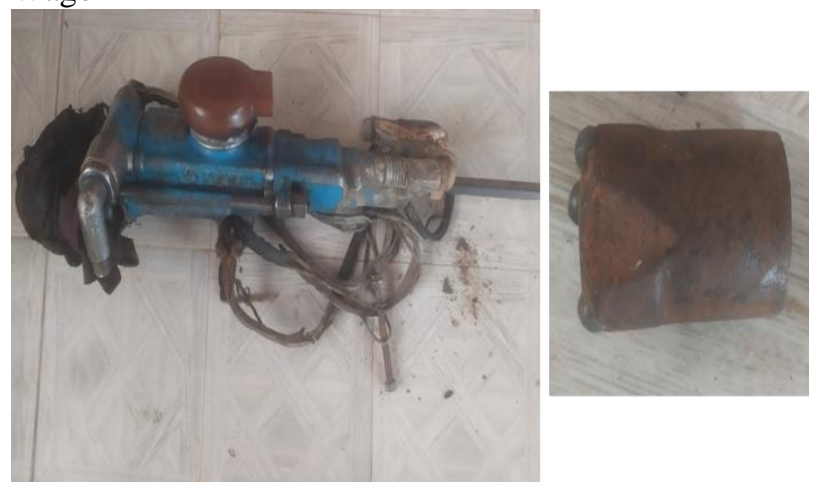

Figure 5:(a) Atlas Copco YT27 Jackhammer (b) 0.9inch Button drilling bit

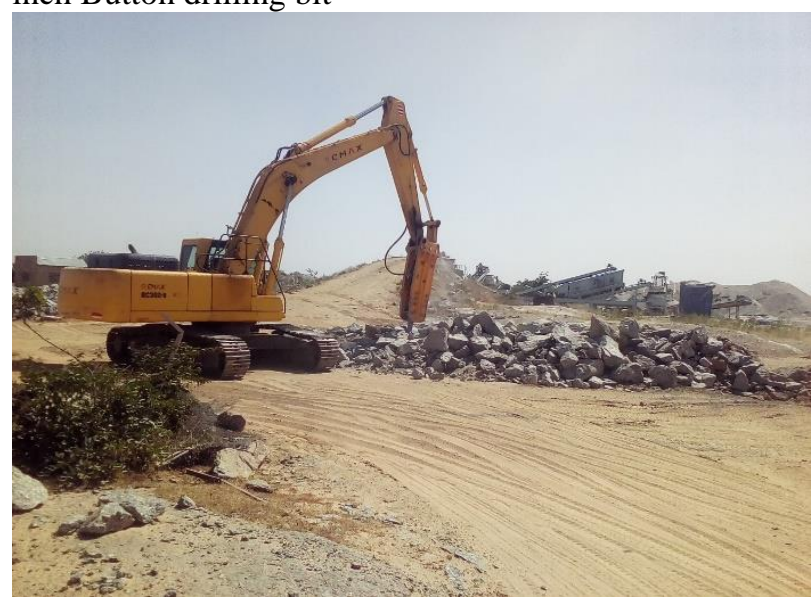

Figure 6: CMAX SC 360-8 Excavator attached with EDT 6500F Rock Breaker

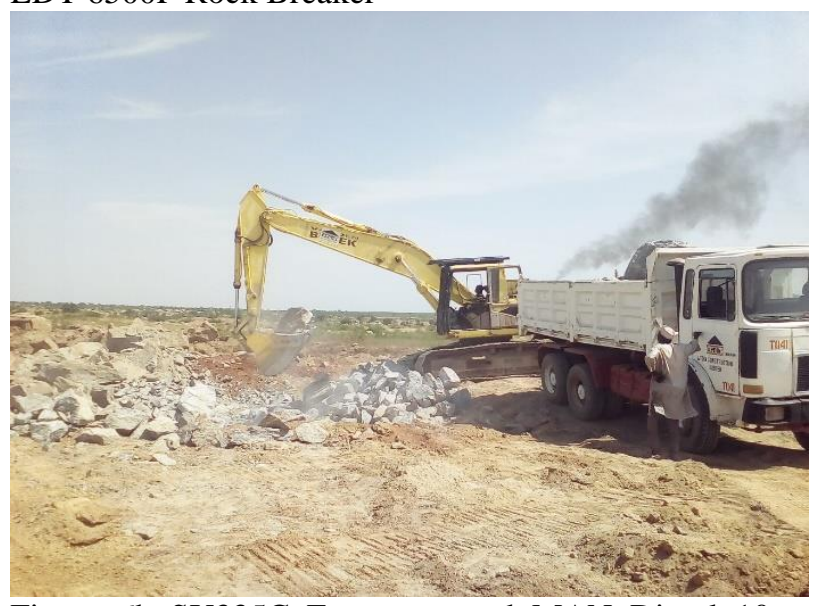

Figure 6b SY335C Excavator and MAN Diesel 10

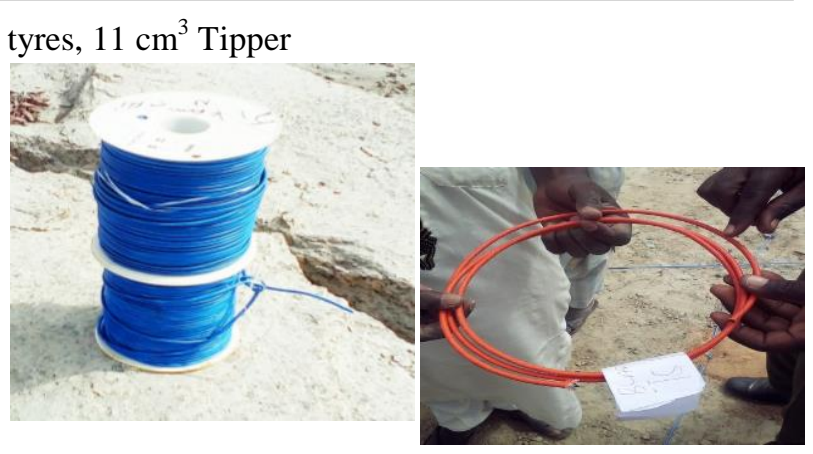

(a)

(b)

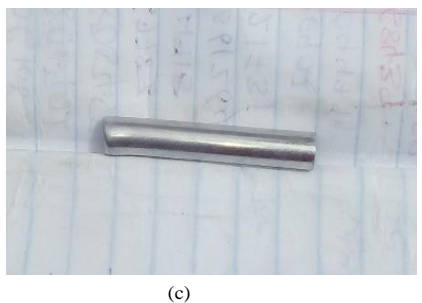

Figure 7: (a) Detonating cord, (b) Safety fuse, and (c) Blasting cap/plain detonator

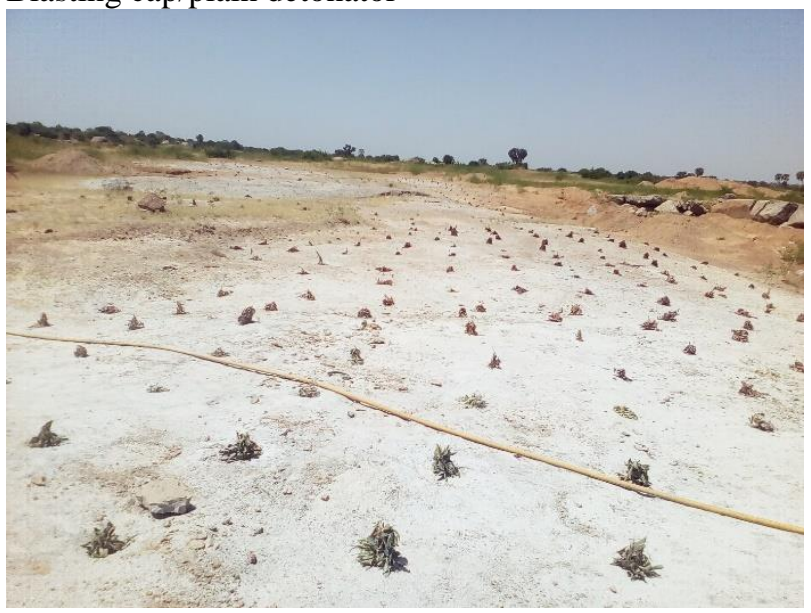

Figure 8: 2x2ft Squared Drilling pattern adopted at the Quarry

\section{Excavators, Rock Cutter/Breaker, and Tippers:}

Excavators have various uses and at the Quarry site, three Excavators, a Rock Breaker two Tippers are used. The CMAX SC 360-8 Excavator is attached with EDT $6500 \mathrm{~F}$ Rock Breaker for mobility and optimum results as shown in Figure 5. It is used to resize boulders that could not be fed into crusher feeder because of oversize. Likewise, Figure 6 shows SY335C Excavator used for loading the blasted rocks on MAN Diesel Tipper at the Quarry. The Tippers haul the loaded rock boulders to the crushing plant. Detonating cord, Safety fuse, and Blasting cap/plain detonator (for igniting the blasting): The detonating cord shown in Figure $7 \mathrm{a}$ is a rounded flexible cord containing a centre core of high explosive which can detonate at a rate of about $700 \mathrm{~m} / \mathrm{s}$. It is covered with various combinations of materials such as waterproof material, plastic, etc for protection against damage and flexibility. Its main usage is to initiate charges of explosives through exploding the cord. This must be initiated by the blasting cap shown in Figure 7c. the detonating cord can be used to initiate/fire as many holes as can be drilled per blasting. Figure $7 \mathrm{c}$ shows a plain detonator which is an aluminium tube charged with 
a base of a powerful high explosive PETN and a primary charge of lead azide and lead styphnate. The latter mixture explodes first when initiated by the split of the safety fuse shown in Figure 7b, and in turn, detonates the base charge. The plain detonator serves as an initiator of high explosives and is very useful in blasting based on the condition it is used. Other types of detonators exist, but at the Quarry, Plain detonators are used because they adopt a non-electric firing system.

\section{Results from Drilling Operations Drilling Pattern:}

Figure 8 shows the result of blast holes drilled using Atlas Copco YT27 Jackhammer drilling machine and $2 \times 2 \mathrm{ft}$ squared drilling pattern. As can be seen, the openings of the holes were covered with shrubs to prevent blockage. The $2 \times 2 \mathrm{ft}$ squared drilling pattern used in this blasting yielded optimum blast fragmentation results because it pits the drilled hole diameter and depth. This specific pattern was chosen to reduce the costs of rock crushing and then improve the operational effectiveness.

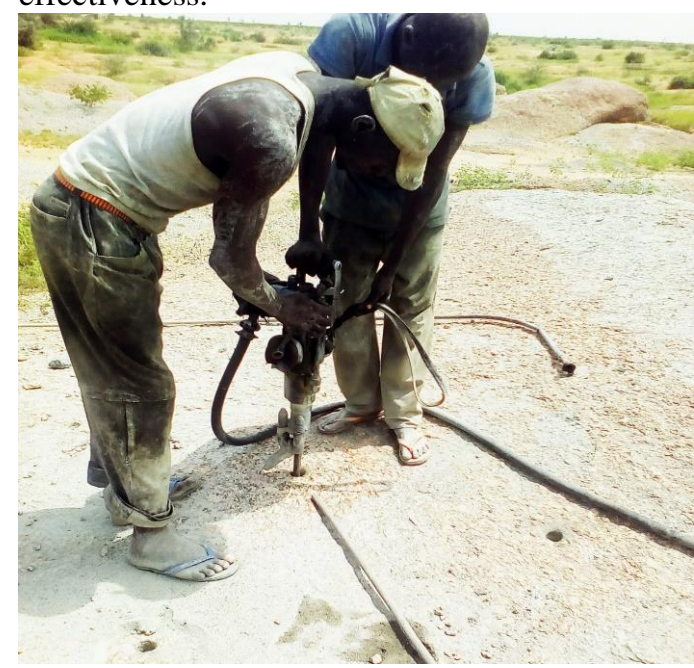

Figure 9: Drilling holes

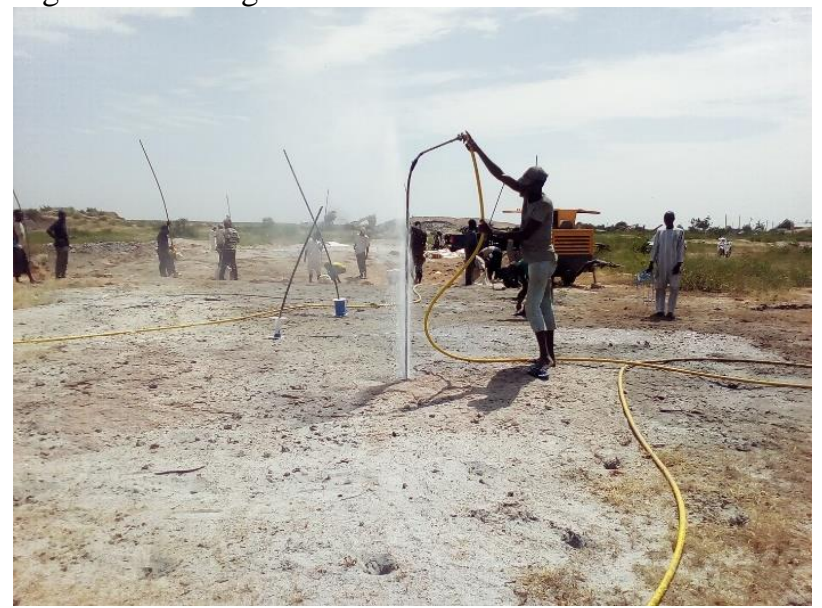

Figure 10: Flushing of the drilled hole.

\section{Drilling Hole Parameters:}

Figure 9 showed one of the blast holes drilled during the research work. These holes were drilled vertically to the slope of the bench with a Jackhammer machine. The holes had diameters of $32 \mathrm{~mm}$ each, spacing and burden of 0.6 each, and depths of $3.66 \mathrm{~m}$ each. The holes were charged with ANFO explosives from the bottom to the stemming as shown in Figure 10.

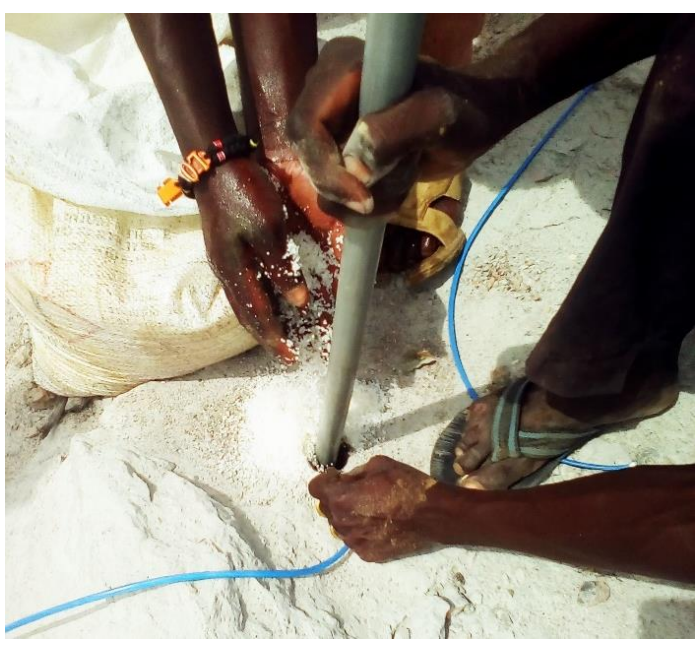

Figure 11: Charging of drilled holes with ANFO

Figure 10 showed flushing of drilled holes before charging, using the air compressor. This was necessary because ANFO explosive is soluble in water therefore the holes needed to be free of sands, dry leaves, or water. Also, drill hole depth is one of the parameters necessary for optimum fragmentation, hence there was a need to maintain the designed and drilled depth.

\section{Results from Blasting Operations}

Figure 11 showed bottom charging using ANFO, from the Figure, it can be seen that the detonating cord was tied down to the bottom of the hole. The quantities of ANFO required for charging all the blast holes were calculated using parameters as indicated under Weight of Charge of Explosive per Hole $(\mathrm{kg})$. This ANFO explosive charge increased the efficiency of explosives and it occupied about two-third of the blast holes. This helped in the reduction of ground vibration and noise.

Figure 12 showed stemming and detonating cord connection. The stemming was carried out by filling up of uncharged top part of the blast holes with sand materials as shown in Figure 12. This prevented the explosions gas from venting out from the hole. Appropriate stemming was essential because it has a major role in stopping flyrock, air blast problem, and poor fragmentation of the rock above column charge.

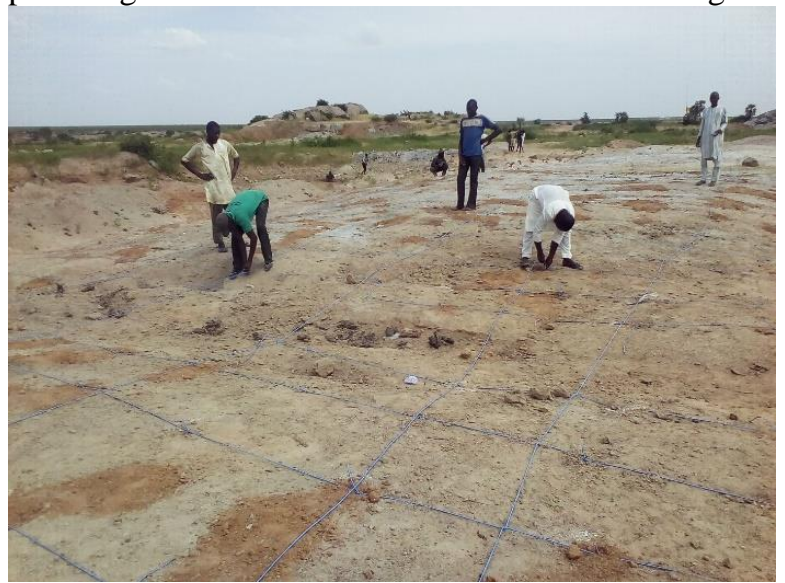

Figure 12: Stemming and Detonating cord connection 
Figure $13 \mathrm{a} \& \mathrm{~b}$ showed results from rock blasting. It can be seen that the fragmentation was good and there were no many flyrocks. Also, the bigger boulders could easily be resized using the rock breaker shown in Figure 5.

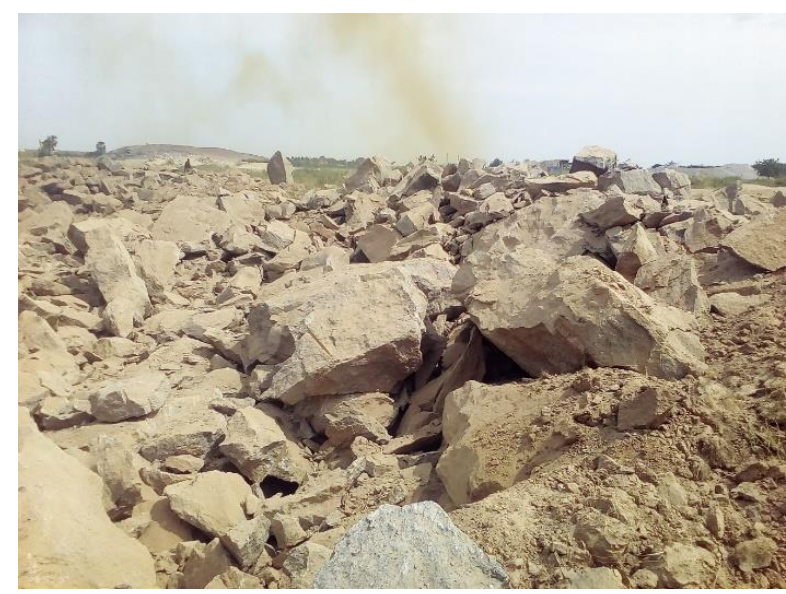

Figure 13a: Rock boulders after blasting

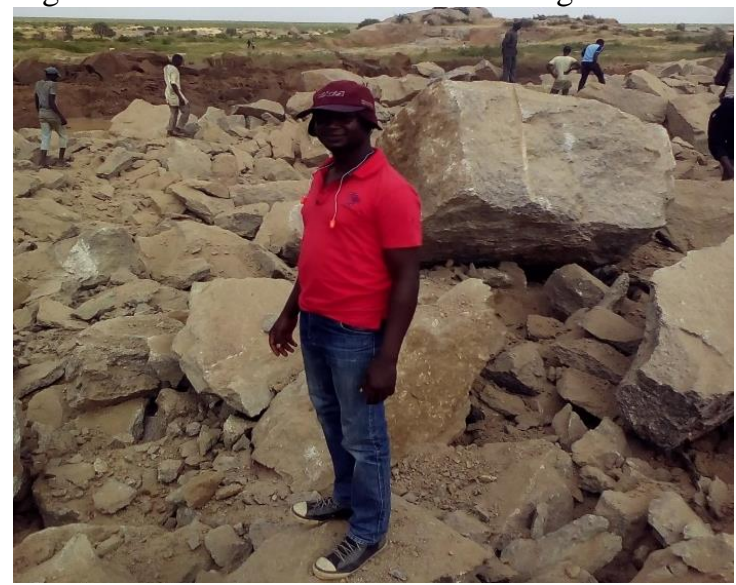

Figure 13b: Rock boulders after blasting

Calculations of Weight of Charge of Explosive per Hole (kg)

The calculation of explosives required for a blasting operation is based on the data received from the drilling section. Below is a typical blasting operation that took place on the $14^{\text {th }}$. October, 2018.

Data received from drill section were:
Blast Location:

Blast Type:

Type of materials:

Total Number of the holes:

Diameter of each hole:

Spacing dimension, $\delta$ :

Burden dimension, $\mathrm{B}$ :
The average depth of drilled holes, $\mathrm{H}: 12 \mathrm{ft}=3.6576$ metres

Granite rock solid density: $2.72 \mathrm{t} / \mathrm{m}^{3}$

Therefore, the calculation of explosives required is as follows;

Unit rock materials volume, $\mu$ per hole

$\mu=\mathrm{B} \times \delta \times \mathrm{H}=1.3592 \mathrm{~m}^{3}$ per hole

Therefore,

The total tonnage of rocks materials $=$

Rock Volume $(\mu)$ per hole $\mathrm{x}$ Density of rock $\left(\mathrm{t} / \mathrm{m}^{3}\right) \mathrm{x}$ Number of holes $(\mathrm{n})=7,394.048 \mathrm{~T}$
Since the Granite outcrop is a hard rock, it is Powder Factor is given as $0.8 \mathrm{~kg} / \mathrm{m}^{3}=0.8=0.2825173338 \mathrm{~kg} / \mathrm{T}$

Quantity of Explosive required =

Total Tonnage $\mathrm{x}$ Powder factor $=2,088.95 \mathrm{~kg}$

Quantity of High Explosive to Low Explosive (ANFO)

H. E. $10 \%$ L. E. $90 \%$

High Explosive required $=208.895 \mathrm{~kg}$

\section{Implications of Quarrying Activities on the Staff, Residents, and Settlements}

Figure 14 is a result of immediate blasting at the quarry which led to air pollution within the quarry environment. Inhalation of this polluted air in the surroundings could be dangerous and may lead to serious occupational hazards. As reported by Aryafar (2020); Nandi et al. (2018); Ahmad, (2015); Yadav et al. (2011), the dust from blast explosion and crushing at quarries over time lead to silicosis and other lung-related ailments. This dust in the quarry atmosphere usually occurs when there is poor fragmentation of rocks, though it may be due to dry soil as overburden on the rock outcrop.

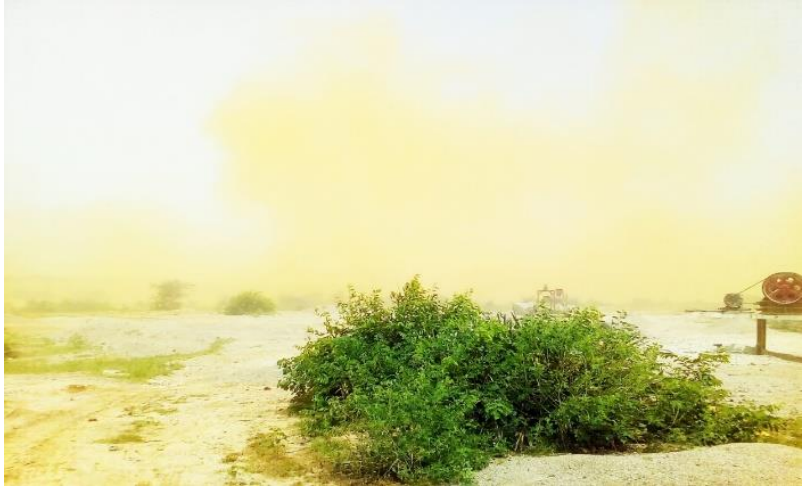

Figure 14: Specks of dust and other chemicals after blasting

\section{Discussion and Conclusion}

This paper has established that adequate fieldwork participation and proper methodologies can be used effectively to assess drilling and blasting techniques at any given site location. Though the company has brought jobs and livelihood to the nearby community (because most of the lower manpower workers are from the community); it has also negatively affected the people because of the thunderous sounds from blasting and scattering of rock fragments from the blasting, this has a longer unnoticed hearing challenge (Burgess and Reist, 1969) and dusty environment which may cause silicosis disease (Nandi et al. 2018; Ahmad, 2015; and Yadav et al. 2011). Also, blasting in the rainy season sometimes causes houses in the nearby communities to crack and /or collapsed, this could be eliminated or reduced by using appropriate blasting parameters.

In the light of all that has been stated so far, the following suggestions are hereby proposed:

i. Fire initiated for the blasting can die up before explosion, hence the Blaster has to go back and check the detonator. This could be dangerous and fatal should the blast explode while the blaster is near the blast 
area. Therefore, electric blasting should be used where suitable.

ii. Wearing of Air muffler and other safety gadgets/ PPEs should be enforced on-site, and defaulters should be sanctioned appropriately, because, smoking, chemicals, and specks of dust coming from the blast explosion and crushing plant over time could result in serious occupational diseases such as Silicosis which is not curable. Likewise, the company should construct a mini-clinic at the quarry plant for emergency purposes.

iii. Parameters such as bench height, blast hole diameter, burden between rows, spacing between blast holes, stemming, and explosives properties should be considered in designing a blast because of their importance in delivering optimum fragmentation of the rock.

iv. The charged holes must be accurately stemmed and avoid stemming shorter than the burden length since overcharging could be ascribed to flyrocks and vibration noticed during most of the blasting operation.

v. The company constructed boreholes to the nearby community as part of community development services, but more opportunities in terms of corporate social responsibilities should be brought to the community. Likewise, the staff of the company should be motivated with incentives to boost their selfconfidence.

\section{Acknowledgements}

This research paper is produced from part of the project I carried out for an award of Postgraduate Diploma in Mining Engineering of the Nigerian Institute of Mining and Geosciences, Jos, Plateau State, Nigeria. I wish to acknowledge Engr. Muhammed Hanny Emetem for his input and contribution to this work and my practical experience. I also recognize the staff of AFDIN quarry sites and plant at Barawa village, Katsina for their technical assistance. I equally acknowledged the contribution of Engr. Dikko Dalhat, Deputy Director, Nigerian Institute of Mining and Geosciences, Jos, Nigeria who supervised my postgraduate research work.

\section{References}

Ahmad, A. (2015). Silicosis, Mining and Occupational Health in India's Sandstone Industry. EHS Journal.

Awwal, D.M. (2017). Review of Modern Blasting Techniques at Dangote Cement Company Obajana, Kogi State, Nigeria, (unpublished PGD Project). Nigerian Institute of Mining and Geosciences, Jos.

Armaghani, D. J., Koopialipoor, M., Bahri, M., Hasanipanah, M., Tahir, M. M. (2020). A SVRGWO technique to minimize flyrock distance resulting from blasting. Bulletin of Engineering Geology and the Environment. doi:10.1007/s10064020-01834-7.

Aryafar, A., Rahimdel, M. J., Tavakkoli, E. (2020). Selection of the Most Proper Drilling and Blasting Pattern by Using MADM Methods (A Case Study: Sangan Iron Ore Mine, Iran). Rudarsko-GeološkoNaftni Zbornik, 35(3), 97-108. doi:10.17794/rgn.2020.3.10
Bala A. (2018) "Geospatial Analyses of Land Degradation Sites in Jos South LGA of Plateau State". M.Sc. Dissertation submitted to the Department of Geomatics, Ahmadu Bello University, Zaria

Burgess, W. A., Reist, P. C. (1969). An Industrial Hygiene Study of Flame Cutting in a Granite Quarry. American Industrial Hygiene Association Journal, 30(2), 107-112. doi:10.1080/00028896909343094

Jack, P.Y. (2018) "Geological field observation During Student Industrial Training Supervision at AFDIN quarry site", Katsina: Unpublished.

Jahed A, D., Hajihassani, M., Monjezi, M., Mohamad, E. T., Marto, A., Moghaddam, M. R. (2015). Application of two intelligent systems in predicting environmental impacts of quarry blasting. Arabian Journal of Geosciences, 8(11), 9647-9665. doi:10.1007/s12517-015-1908-2

Kennedy, B.A. (2009). Surface Mining. 2nd Edition. Society for Mining, Metallurgy, and Exploration, Inc., Colorado, USA

Kononenko, M., Khomenko, O., Savchenko, M., Kovalenko, I. (2019). Method for calculation of drilling-and-blasting operations parameters for emulsion explosives. Mining of Mineral Deposits, 13(3), 22-30. doi.org/10.33271/mining13.03.022

Nandi, S., Burnase, N., Barapatre, A., Gulhane, P., Dhatrak, S. (2018). Assessment of Silicosis Awareness among Stone Mine Workers of Rajasthan State. Indian journal of occupational and environmental medicine, 22(2), 97-100.

Regotunov, A., Sukhov, R., Bersenyov, G. (2020). About transition processes in blast hole drilling at quarries. E3S Web of Conferences, 177, 01008. doi:10.1051/e3sconf/202017701008

Sadeghi, F., Monjezi, M., Armaghani, D.J. (2019). Evaluation and Optimization of Prediction of Toe that Arises from Mine Blasting Operation Using Various Soft Computing Techniques. Natural Resources Research. doi:10.1007/s11053-019-096052.

Sergey, A.V., Georgij, S.K., Sergeevich, K., Aleksandr, K.K., Andrey, O.S., Anna, A.S. (2017). Destruction of Rock Upon Blasting of Explosive Agent. ARPN Journal of Engineering and Applied Sciences. ISSN $1819-6608$

Singh, P. (2020). Study of Stone Quarrying and Silicosis in Jodhpur District. Journal of Global Resources, 6(01), 118-121.

Tejado, J. J., Guillén, J., Baeza, A. (2016). Assessment of occupational exposure in a granite quarry and processing factory. Journal of Radiological Protection, 36(3), 641-652. doi:10.1088/09524746/36/3/641.

Yadav, S. P., Anand, P. K., Singh, H. (2011). Awareness and Practices about Silicosis among the Sandstone Quarry Workers in Desert Ecology of Jodhpur, Rajasthan, India. Journal of Human Ecology, 33(3), 191-196. doi:10.1080/09709274. 2011.11906359 